\title{
Interstitial lung disease associated with systemic sclerosis (SSC-ILD)
}

\author{
Vincent Cottin ${ }^{1 *}$ and Kevin K. Brown ${ }^{2}$
}

\begin{abstract}
Background: Systemic sclerosis (SSC) is a rare connective tissue disease with a heterogeneous clinical course. Interstitial lung disease (ILD) is a common manifestation of SSC and a leading cause of death.

Main body: All patients newly diagnosed with SSc should receive a comprehensive clinical evaluation, including assessment of respiratory symptoms, a high-resolution computed tomography (HRCT) scan of the chest, and pulmonary function tests. ILD can develop in any patient with SSc, including those with pulmonary hypertension, but the risk is increased in those with diffuse (rather than limited) cutaneous SSc, those with anti-Scl-70/antitopoisomerase I antibody, and in the absence of anti-centromere antibody. While it can occur at any time, the risk of developing ILD is greatest early in the course of SSC, so patients should be monitored closely in the first few years after diagnosis. An increased extent of lung fibrosis on HRCT and a low forced vital capacity (FVC) are predictors of early mortality. While not all patients will require treatment, current approaches to the treatment of progressive SSc-ILD focus on immunosuppressant therapies, including cyclophosphamide and mycophenolate mofetil. In patients with severe and/or rapidly progressive disease, both haematopoietic stem cell transplantation (HSCT) and lung transplantation have been successfully used. A number of medications, including the two drugs approved for the treatment of idiopathic pulmonary fibrosis (IPF), are under active investigation as potential new therapies for SSC-ILD.
\end{abstract}

Conclusions: Physicians managing patients with SSC should maintain a high level of suspicion and regularly monitor for ILD, particularly in the first few years after diagnosis.

\section{Background}

Systemic sclerosis (SSc) is a rare connective tissue disease that is believed to be triggered, in genetically susceptible individuals, by environmental events. SSc is characterised by immune dysfunction, vasculopathy, cellular inflammation and fibrosis of the skin and multiple internal organs $[1,2]$ (Fig. 1). Patients with SSc can be classified by the extent of skin involvement: in patients with limited cutaneous SSc (lcSSc), the affected skin is restricted to the hands, forearms, feet, and face, while in patients with diffuse cutaneous SSc (dcSSc), the affected skin extends proximal to the elbows, and may involve the trunk [3].
The lung is frequently involved in SSc, with interstitial lung disease (ILD) a common manifestation $[4,5]$. Indeed, ILD is included in the American College of Rheumatology (ACR)/ European League Against Rheumatism Collaborative Initiative (EULAR) joint classification criteria to identify SSc in individuals who do not have skin thickening of the fingers extending proximal to the metacarpophalangeal joints [6]. ILD associated with SSc (SSc-ILD) is usually detected during the evaluation of a patient suspected or known to have SSc, but may be the initial presentation of the disease in some patients [7].

In this article, we provide an overview of the identification, assessment, clinical course and management of SSc-ILD, including therapies under investigation.

\section{Diagnosis and assessment of SSC-ILD}

In 2013, ACR and EULAR published new criteria for the classification of SSc [6]. The system was tested in patients with SSc and control patients with diseases similar

\footnotetext{
* Correspondence: vincent.cottin@chu-lyon.fr

${ }^{1}$ National Reference Center for Rare Pulmonary Diseases, Louis Pradel Hospital, Claude Bernard University Lyon 1, 28 Avenue du Doyen Lepine, 69677 Lyon Cedex, Lyon, France

Full list of author information is available at the end of the article
} 


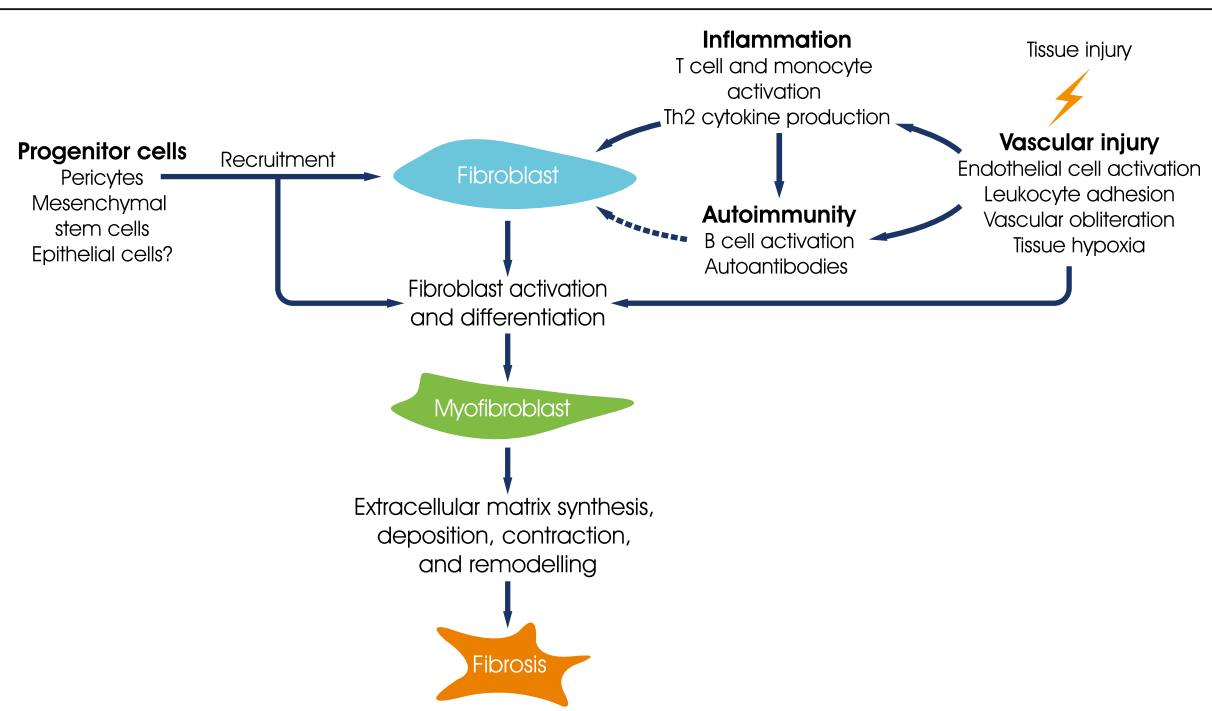

Fig. 1 The pathogenesis of SSC (Adapted from [2]). SSc is initiated by microvascular injury, inducing inflammation, an autoimmune response, and fibroblast activation and differentiation. Activated myofibroblasts perform a series of functions, culminating in excess deposition of extracellular matrix and the development of fibrosis. Republished with permission of The Journal of Clinical Investigation, from Systemic sclerosis: a prototypic multisystem fibrotic disorder, Varga J and Abraham D, Volume No. 117, Edition No. 3, 2007; permission conveyed through Copyright Clearance Center, Inc.

to SSc, and validated with a group of SSc experts. The new criteria were shown to have a sensitivity of $91 \%$ and a specificity of $92 \%$ for detecting SSc. Skin thickening of the fingers extending proximal to the metacarpophalangeal joints is recognized as sufficient for a patient to be diagnosed as having SSc. If this is not present, seven other variably weighted clinical features are considered: skin thickening of the fingers, finger tip lesions (digital tip ulcers or pitting scars), telangiectasia, abnormal nailfold capillaroscopy, pulmonary arterial hypertension and/or ILD, Raynaud's phenomenon, and SSc-related autoantibodies (anticentromere, anti-topoisomerase I, anti-RNA polymerase III).

Risk factors for the development or progression of ILD in patients with SSc include the presence of dcSSc [8], African-American ethnicity [9], older age at disease onset [8], shorter disease duration [10], and the presence of anti-Scl-70/anti-topoisomerase I antibody and/or absence of anticentromere antibody [8]. However, none of these risk factors is absolute. It is important that physicians are aware that ILD may develop in patients with limited cutaneous SSc as well as in patients with diffuse skin disease. The identification of SSc-ILD requires a high level of suspicion as not all patients will have respiratory symptoms [11]. All patients diagnosed should receive a comprehensive clinical assessment, including assessment of respiratory symptoms, chest imaging with a high resolution computed tomography (HRCT) scan, and pulmonary function tests (PFTs), to ensure early identification of ILD and provide baseline measurements to compare with future assessments. The presence of
SSc-ILD is defined by the identification of fibrotic features on chest HRCT or standard chest $\mathrm{x}$-ray, generally most pronounced in the lung bases, and/or when crackles that sound like 'Velcro' being torn apart are heard on chest auscultation (when not due to another cause) [6]. The most common imaging pattern observed on HRCT is non-specific interstitial pneumonia (NSIP) [12]. Pleuroparenchymal fibroelastosis (PPFE)-like lesions on HRCT may also be seen and appear to be associated with poor prognosis [13]. The most common histopathologic pattern seen on surgical lung biopsy is NSIP [14], though surgical lung biopsy is seldom performed in SSc patients, unless the HRCT pattern is atypical, there is suspicion of a different diagnosis, or a complication such as cancer.

The risk of developing ILD is greatest early in the course of SSc, and PFTs can be useful every 4-6 months in the first 3 years after an SSc diagnosis to ensure early detection and to monitor for progression [15]. PFTs in patients with SSc-ILD generally demonstrate a restrictive pattern, with reduced forced vital capacity (FVC) and diffusion capacity of the lung for carbon monoxide (DLco) [16]. However, even in patients with clear fibrosis on HRCT, FVC may be normal [17]. As a reduced DLco may be a result of pulmonary hypertension and/or emphysema rather than, or in addition to, $\operatorname{ILD}[18,19]$, it is important that $\mathrm{DL}_{\mathrm{CO}}$ be interpreted within the entire clinical context. European Society of Cardiology (ESC)/ European Respiratory Society (ERS) guidelines recommend that patients with SSc should be screened for $\mathrm{PH}$ to ensure early detection [20]. 


\section{Clinical course of SSC-ILD}

SSc-ILD is associated with early mortality. In a study of causes of death in 1508 patients with SSc from a single US centre, deaths attributed to pulmonary fibrosis increased from 6\% in 1972-1976 to 33\% in 1997-2001, making ILD the most frequent cause of SSc-related death (Fig. 2) [21]. Similarly, in an analysis of 5850 patients in the EULAR Scleroderma Trials and Research Group (EUSTAR) database, pulmonary fibrosis was responsible for $35 \%$ of SSc-related deaths from 2004 to 2008 [22]. An analysis of death certificates from 2719 French patients with SSc who died between 2000 and 2011 found that almost half of these deaths were due to cardiac or respiratory causes, and that the proportion of deaths related to SSc rather than other causes, increased over this period [23].

SSc-ILD has a variable clinical course. Most patients will experience a slow decline in lung function, but some progress rapidly after disease onset [24-26], with progression defined by an increase in the extent of pulmonary fibrosis on HRCT or by a decline in PFTs [27-29]. Among patients in the EUSTAR cohort, $65 \%$ of patients had DLco $<80 \%$ predicted and $31 \%$ had FVC $<80 \%$ predicted 1 year after the onset of Raynaud's phenomenon [10]. Both the extent of fibrosis on HRCT and a low FVC are independent predictors of mortality [30, 31]. A simple staging system, often referred to as the Goh criteria, which divides patients into those with extensive disease $(>30 \%$ disease extent on HRCT, or $10-30 \%$ disease extent on HRCT and FVC $<70 \%$ predicted) or limited disease $(<30 \%$ disease extent on HRCT, or $10-30 \%$ disease extend on HRCT and FVC $\geq 70 \%$ predicted) demonstrated that extensive disease was a powerful predictor of mortality (hazard ratio 3.46, 95\% confidence interval [CI] 2.19, 5.46) (Fig. 3) [30]. In a separate study, when the prognostic significance of PFT trends at 1 year on 15-year survival were analyzed, the most accurate predictor of mortality was a relative decline in FVC of $\geq 10 \%$, or a relative decline in FVC of $5-9 \%$ with a relative decline in DLco of $>15 \%$ [27]. However, neither of these prognostic indices has been prospectively studied as a guide to treatment in SSc-ILD patients. There is no evidence that the pattern of fibrosis on HRCT or histology (e.g. NSIP versus UIP) has a significant impact on disease progression or mortality in patients with SSc.

\section{Management of SSc-ILD}

While there are no approved drugs for SSc-ILD, current approaches to treatment include routine follow-up alone (watchful waiting), or routine follow-up with active immunosuppression in patients with progressive ILD [32]. The latest treatment guidelines for SSc, issued in 2016 [33], reiterated the recommendation given in the 2009 guidelines [34] that tailored treatment with CYC should be considered, particularly in patients with progressive disease. They also included a new recommendation for consideration of autologous haematopoietic stem cell transplantation (HSCT) in selected patients with rapidly progressive SSc at risk of organ failure. Given the potential for serious adverse outcomes (including death) with HSCT, this approach requires careful evaluation of individualized risks and benefits. Importantly, the latest treatment guideline was completed prior to publication of the results of the Scleroderma Lung Study II (SLS II), which showed that treatment with mycophenolate mofetil (MMF) for 2 years had comparable efficacy with oral CYC for 1 year followed by placebo for the second year [35].

Based on the available data, treatment decisions need to be made on a case by case basis. Not all patients will need therapy; however, active treatment should be considered when there is clinically significant disease at

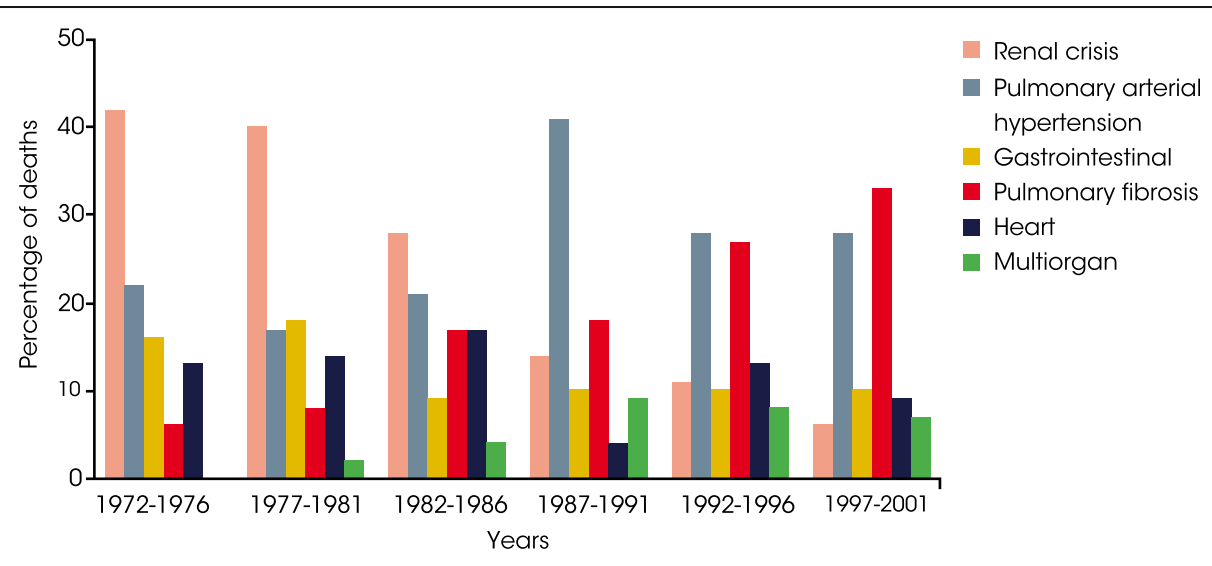

$p<0.001$ for changes in frequency of death due to renal crisis and pulmonary fibrosis from 1972-1976 to 1997-2001.

Fig. 2 Causes of SSc-related deaths between 1972 and 2001 (Adapted from [21]). Reproduced from Ann Rheum Dis, Steen VD and Medsger TA, Volume 66, Pages 940-44, 2007, with permission from BMJ Publishing Group Ltd. 


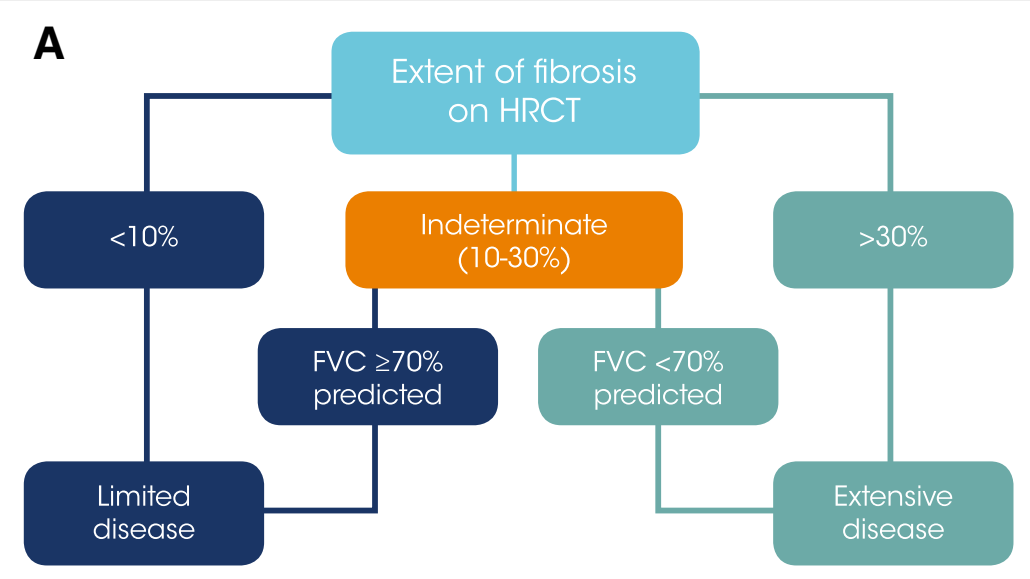

B

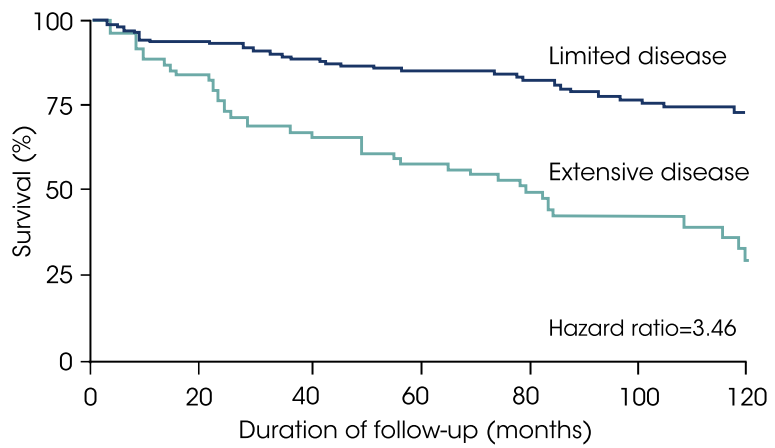

Fig. 3 A simple staging system for prediction of survival in patients with SSC-ILD. a Patients with SSc may be classified as having limited disease or extensive disease based on the extent of fibrosis seen on HRCT of the lungs, plus FVC per cent predicted in patients with 10-30\% fibrosis on HRCT. b Extensive lung disease is a significant predictor of mortality with a hazard ratio of 3.46 compared to limited disease [30]. Reprinted with permission of the American Thoracic Society. Copyright@ 2018 American Thoracic Society. Goh NS et al. 2008. Interstitial lung disease in systemic sclerosis: a simple staging system. Am J Respir Crit Care Med 2008;177:1248-54. The American Journal of Respiratory and Critical Care Medicine is an official journal of the American Thoracic Society

presentation or evidence of disease progression, as measured by a decline in lung function, progression of fibrosis on HRCT, or worsening respiratory symptoms due to ILD, and it is the patient's preference [15, 36, 37]. While treatment may not be needed initially, as disease progression may occur at any time, routine monitoring is essential [15].

\section{Cyclophosphamide}

The results of two randomised placebo-controlled trials of CYC in SSc-ILD support its use [16, 38]. In the FAST study, in which patients received low-dose prednisolone plus intravenous CYC for 6 months followed by azathioprine therapy for 6 months, or placebo for 12 months, there was a trend towards improvement in FVC with active treatment, but only $68 \%$ of patients in the active treatment group and $57 \%$ of those who received placebo completed 1 year of treatment [38]. In Scleroderma Lung Study (SLS) I, patients were randomised to receive oral CYC or placebo for 12 months, but only 54 patients (68.4\%) in the CYC group and 55 (69.6\%) in the placebo group completed 12 months of treatment. At month 12, there was a significant difference in favour of CYC in the primary endpoint of change from baseline in FVC \% predicted (- 1.0 vs $-2.6 \%$ predicted; Fig. 4). Significant differences between CYC and placebo were also reported for changes from baseline in total lung capacity ( $-0.3 \mathrm{vs}-2.8 \%$ predicted), skin thickness (mRSS: -3.6 vs -0.9 units), dyspnoea (Mahler transitional dyspnoea index: +1.4 vs -1.5 units) and the Health Assessment Questionnaire disability index (-0.1 vs 0.2$)$ at month 12 [16]. Adverse events occurred in a greater proportion of patients treated with CYC and included leucopenia $(26.0 \%$ vs $0 \%)$, haematuria $(12.3 \%$ vs $4.2 \%)$, neutropenia $(9.6 \%$ vs $0 \%)$, pneumonia $(6.8 \%$ vs $1.4 \%)$ and anaemia $(2.7 \%$ vs $0 \%)$ [16]. Except for a sustained improvement in dyspnoea, the effects of CYC were not apparent 12 months after discontinuing treatment [39]. Patients with more severe disease at baseline, as measured by a greater extent of disease on HRCT or a greater extent of skin disease (higher modified Rodnan skin score [mRSS]) 


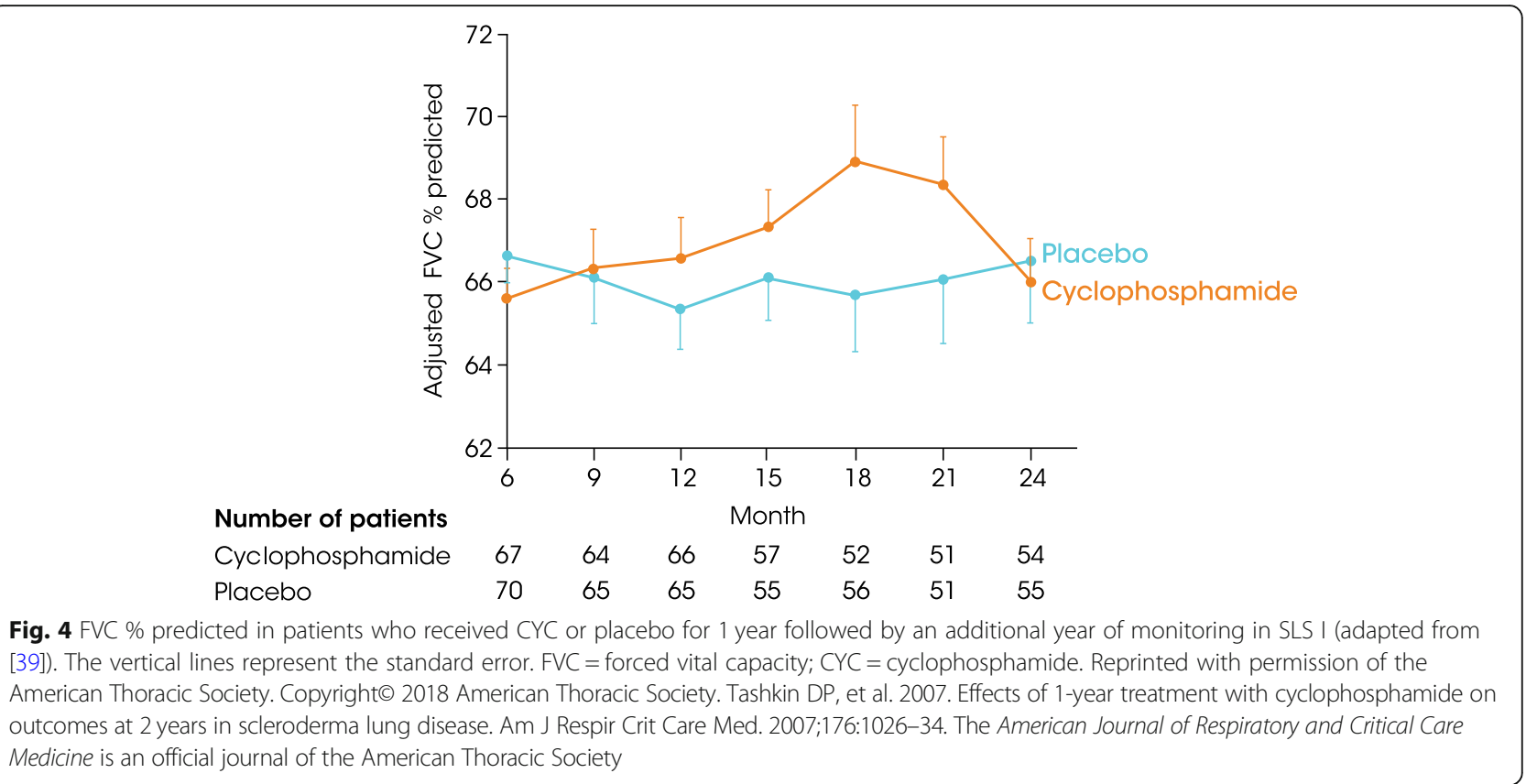

appeared to be more likely to respond to CYC [40]. Of note, very limited decline in FVC was observed in the placebo cohort, suggesting that the population included in this trial had relatively non-progressive ILD.

\section{Mycophenolate mofetil}

MMF is commonly used in the treatment of patients with SSc-ILD [32, 41], and is more commonly used than $\mathrm{CYC}$ in some countries. Observational studies have suggested that MMF treatment may stabilise or even improve FVC [42]. In SLS II, there was no significant difference in the primary endpoint of change from baseline in FVC \% predicted at the end of year 2 between patients who received oral MMF for two years and patients who received oral CYC for 1 year followed by placebo for 1 year $(+2.19 \%$ vs $+2.88 \%$ predicted; difference vs CYC: $-0.70,95 \%$ CI -3.1 to 1.7; Fig. 5) [35]. Both MMF and $\mathrm{CYC}$ resulted in improvements from baseline to end of year 2 in Mahler transitional dyspnoea index $(+1.77$ vs +2.16 units) and mRSS ( -4.90 vs -5.35 units), with no significant difference between treatment groups. There were fewer treatment discontinuations due to adverse events in the MMF group than in the CYC group (35\% vs $42 \%)$.

\section{Haematopoietic stem cell transplantation}

Randomized controlled trials comparing HSCT with CYC have shown at least stability of pulmonary physiology and an improvement in skin thickness in patients with progressive diffuse cutaneous SSc $[43,44]$. In the ASTIS trial, HSCT therapy resulted in significant improvement in FVC at year 2 of follow-up, but had no impact on DLco. Significant adverse effects, including early death, occurred more frequently in the HSCT group. In the HSCT group, there were 8 treatment-related deaths $(10.1 \%)$ in the first year compared with none in the CYC group. However, event-free survival was significantly greater with HSCT compared with CYC at year 1 (HR 0.52 [95\% CI $0.28,0.96])$, year 2 (HR 0.35 [95\% CI 0.16, 0.74] and year 4 (HR 0.34 [95\% CI $0.16,0.74]$ ) [43]. In the ASSIST trial, HSCT and antithymocyte globulin therapy preceded by CYC and filgrastim was superior to CYC with regards to skin score and lung volumes, although no difference was observed in DLco No deaths occurred in either group over 24 months of follow up [44]. Based on these results, EULAR recommendations state that HSCT is a treatment option, but should only be considered in highly selected patients with rapidly progressive disease who are at risk of organ failure and given the high risk of treatment-related adverse effects and early mortality, the experience of the medical team is of high importance [33]. More recently, the SCOT trial in patients with diffuse cutaneous SSc and renal or pulmonary involvement demonstrated greater event-free survival with HSCT than CYC at 54 months $(79 \%$ versus $50 \%$ ) and at 72 months (74\% versus $47 \%$ ) [45].

\section{Lung transplant}

Carefully selected patients with SSc-ILD, who have not responded to treatment and who have no extrapulmonary contraindications, should be considered for lung transplant [46]. In a retrospective analysis of 30 patients with SSc-ILD who underwent lung or heart-lung transplant between 1993 and 2016, survival rates after 1, 3, 


\section{Number of patients \\ Cyclophosphamide \\ Mycophenolate mofetil}

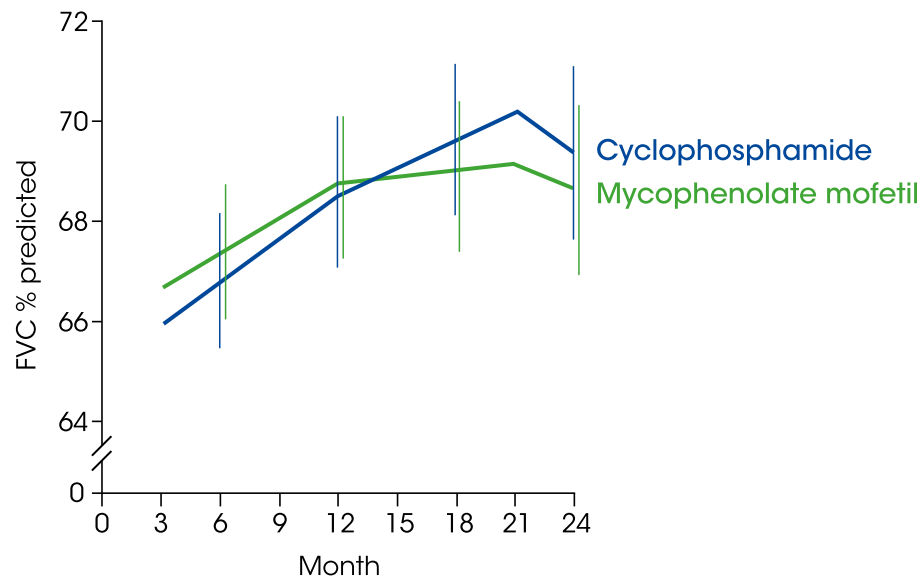

$\begin{array}{lllllllll}72 & 62 & 56 & 51 & 51 & 44 & 46 & 40 & 51\end{array}$

Fig. 5 Effect of MMF for 2 years vs CYC for 1 year followed by placebo for 1 year on FVC \% predicted in SLS II (adapted from [35]). The vertical lines represent the $95 \% \mathrm{Cl}$. Reprinted from The Lancet Respir Med, Volume 4, Tashkin DP, et al. Mycophenolate mofetil versus oral cyclophosphamide in scleroderma-related interstitial lung disease (SLS II): a randomised controlled, double-blind, parallel group trial, Pages 708-19, Copyright (2016), with permission from Elsevier

and 5 years were 93, 76, and 60\% [47]. Similarly, in a retrospective analysis of survival after lung transplant at a single US centre, survival in patients with SSc was $81 \%$ at 1 year and $66 \%$ at 5 years, similar to the rates observed in patients with other fibrotic ILDs [48]. However, lung transplantation in patients with SSc is possible in only a minority of patients, with transplant contraindicated in many cases due to active systemic disease, severe parietal thoracic involvement, and/or an increased risk of aspiration arising from oesophageal dysmotility and gastroparesis.

\section{Supportive care}

Patients with SSc-ILD should receive appropriate supportive care, which may include pulmonary rehabilitation, patient and caregiver education and other activities that aim to reduce symptoms and improve HRQL. Pulmonary rehabilitation has been shown to improve exercise capacity (6-min walk distance), dyspnoea and HRQL in patients with ILD [49]. However, further research is needed to establish the effectiveness of non-pharmacological interventions [50]. Palliative care should be available to patients at all stages of illness and should be individualised based on patient needs [51]. Management of comorbidities and treatment-related complications is an important part of the overall management of patients with SSc-ILD and should be part of routine care.

\section{Investigational therapies}

Based on the clinical and mechanistic similarities between SSc-ILD and idiopathic pulmonary fibrosis (IPF), the two approved therapies for IPF, nintedanib and pirfenidone, are being investigated as potential treatments for
SSc-ILD. Nintedanib inhibits the proliferation, migration and differentiation of fibroblasts and the secretion of extracellular matrix, and has demonstrated antifibrotic, anti-inflammatory and vascular remodelling effects in animal models of SSc and ILD [52-54]. The efficacy and safety of nintedanib as a treatment for SSc-ILD are being assessed in the randomised placebo-controlled SENSCIS $^{\circ}$ trial (ClinicalTrials.gov NCT02597933; EudraCT 2015-000392-28) [55]. At baseline, participants were aged $\geq 18$ years with first non-Raynaud symptom $\leq 7$ years before screening, $\geq 10 \%$ fibrosis on HRCT of the lungs, FVC $\geq 40 \%$ predicted and DLco $30-89 \%$ predicted. Patients receiving low-dose prednisone and/or stable background therapy with MMF or methotrexate were eligible to participate. A total of 580 patients were randomised 1:1 to receive nintedanib $150 \mathrm{mg}$ twice daily (bid) or placebo, stratified by the presence of anti-Scl-70/anti-topoisomerase I antibody. The primary endpoint is the annual rate of decline in FVC (mL/year) assessed over 52 weeks. Key secondary endpoints are absolute changes from baseline to week 52 in the mRSS and in the St George's Respiratory Questionnaire (SGRQ) total score, which has been endorsed by an expert working group as a measure of HRQL in trials in SSc-ILD [56].

The precise mechanism of action of pirfenidone is unclear, but it has exhibited a number of effects in vitro and in animal models that may be relevant to its ability to slow the progression of pulmonary fibrosis, e.g., inhibited proliferation and differentiation of fibroblasts and reduced synthesis of collagen [57-59]. This may be mediated, at least in part, through inhibitory effects on GLI transcription factors [60]. In the Phase II LOTUSS study, a 
16-week open-label trial of pirfenidone in patients with SSc-ILD, the adverse event profile of pirfenidone was acceptable, similar to that seen in patients with IPF, and not affected by concomitant use of MMF, although a longer titration period may be associated with better tolerability
[61]. The effects of pirfenidone vs placebo in patients with SSc-ILD who are receiving MMF are being investigated in SLS III (ClinicalTrials.gov NCT03221257). The RELIEF trial, which investigated the efficacy and safety of pirfenidone vs placebo given on top of anti-inflammatory

Table 1 Ongoing and recently completed Phase II/III randomized controlled trials of potential treatments for SSc-ILD listed on ClinicalTrials.gov

\begin{tabular}{|c|c|c|c|c|c|}
\hline Agent (company) & Type of molecule & $\begin{array}{l}\text { Trial name } \\
\text { (ClinicalTrial.gov identifier) }\end{array}$ & $\begin{array}{l}\text { Population; sample } \\
\text { size }\end{array}$ & Lung function endpoint/s & $\begin{array}{l}\text { Estimated primary } \\
\text { completion date }^{a}\end{array}$ \\
\hline $\begin{array}{l}\text { Lanifibranor } \\
\text { (Inventiva Pharma) }\end{array}$ & $\begin{array}{l}\text { Peroxisome } \\
\text { proliferator-activated } \\
\text { receptor agonist }\end{array}$ & FASST (NCT02503644) & $\begin{array}{l}\text { Patients with } \\
\text { dcSSc; } n=132\end{array}$ & $\begin{array}{l}\text { Changes from baseline } \\
\text { in FVC \% predicted and } \\
\text { DLco \% predicted at } \\
\text { weeks } 24 \text { and } 48 \\
\text { (secondary endpoints) }\end{array}$ & October 2017 \\
\hline $\begin{array}{l}\text { Anabasum / lenabasum } \\
\text { (Corbus Pharmaceuticals) }\end{array}$ & & $\begin{array}{l}\text { RESOLVE-1 } \\
\text { (NCT03398837) }\end{array}$ & $\begin{array}{l}\text { Patients with } \\
\text { dcSSc; } n=354\end{array}$ & $\begin{array}{l}\text { Change from baseline } \\
\text { in FVC at week } 53 \\
\text { (secondary endpoint) }\end{array}$ & March 2020 \\
\hline Riociguat (Bayer) & $\begin{array}{l}\text { Guanylate cyclase } \\
\text { stimulator }\end{array}$ & RISE-SSC (NCT02283762) & $\begin{array}{l}\text { Patients with } \\
\text { dcSSc; } n=121\end{array}$ & $\begin{array}{l}\text { Change from baseline i } \\
\text { n FVC \% predicted at } \\
\text { week } 52 \text { (secondary } \\
\text { endpoint) }\end{array}$ & October 2018 (actual) \\
\hline $\begin{array}{l}\text { Tocilizumab } \\
\text { (Hoffmann-La Roche) }\end{array}$ & $\begin{array}{l}\text { Interleukin-6 receptor } \\
\text { antagonist }\end{array}$ & focuSSced (NCT02453256) & $\begin{array}{l}\text { Patients with } \\
\text { SSc and mRSS } \\
\text { of } 10-35 \\
n=212\end{array}$ & $\begin{array}{l}\text { Change from baseline } \\
\text { in FVC at week } 48 \\
\text { (secondary endpoint) }\end{array}$ & January 2018 (actual) \\
\hline $\begin{array}{l}\text { Abatacept (Bristol- } \\
\text { Myers Squibb) }\end{array}$ & $\begin{array}{l}\text { Elective T-cell } \\
\text { costimulation } \\
\text { modulator }\end{array}$ & ASSET (NCT02161406) & $\begin{array}{l}\text { Patients with } \\
\text { dcSSc; } n=88\end{array}$ & $\begin{array}{l}\text { Change from baseline } \\
\text { in FVC \% predicted at } \\
\text { week } 52 \text { (secondary } \\
\text { endpoint) }\end{array}$ & September 2018 \\
\hline $\begin{array}{l}\text { Nintedanib (Boehringer } \\
\text { Ingelheim) }\end{array}$ & $\begin{array}{l}\text { Tyrosine kinase } \\
\text { inhibitor }\end{array}$ & SENSCIS (NCT02597933) & $\begin{array}{l}\text { Patients with } \\
\text { SSC-ILD; } \\
n=580\end{array}$ & $\begin{array}{l}\text { Annual rate of decline } \\
\text { in FVC (mL/year) over } \\
52 \text { weeks (primary } \\
\text { endpoint) }\end{array}$ & October 2018 \\
\hline $\begin{array}{l}\text { Ifetroban (Cumberland } \\
\text { Pharmaceuticals) }\end{array}$ & $\begin{array}{l}\text { Antagonist of } \\
\text { thromboxane } \\
\text { A2 / prostaglandin } \\
\text { endoperoxide } \\
\text { receptor }\end{array}$ & NCT02682511 & $\begin{array}{l}\text { Patients with } \\
\text { dcSSc }(n=14) \\
\text { or SSc-PAH } \\
(n=20)\end{array}$ & $\begin{array}{l}\text { Changes from baseline } \\
\text { in FVC and DLco at } \\
\text { weeks } 12,26,52 \\
\text { (secondary endpoints) }\end{array}$ & December 2019 \\
\hline Pirfenidone (Genentech) & Pyridone analogue & NCT03068234 & $\begin{array}{l}\text { Patients with } \\
\text { SSc; } n=72\end{array}$ & $\begin{array}{l}\text { Secondary endpoints: } \\
\text { - Changes from baseline } \\
\text { in FVC and DLco at } \\
\text { weeks } 24 \text { and } 52 \\
\text { - Assessment of chest } \\
\text { CT at weeks } 24 \text { and } 52\end{array}$ & April 2019 \\
\hline Pirfenidone (Genentech) & Pyridone analogue & SLS III (NCT03221257) & $\begin{array}{l}\text { Patients with } \\
\text { SSc-ILD on } \\
\text { background } \\
\text { MMF; } n=150\end{array}$ & $\begin{array}{l}\text { Changes from baseline } \\
\text { at month } 18 \text { in: } \\
\text { - FVC \% predicted } \\
\text { (primary endpoint) } \\
\text { - DLco \% predicted } \\
\text { - Mahler Modified } \\
\text { Transitional Dyspnoea } \\
\text { Index } \\
\text { - Total lung capacity } \\
\text { (HRCT) } \\
\text { - SGRQ total score }\end{array}$ & April 2021 \\
\hline $\begin{array}{l}\text { Rituximab (study funded } \\
\text { by UK Medical Research } \\
\text { Council and National } \\
\text { Institute for Health } \\
\text { Research) }\end{array}$ & $\begin{array}{l}\text { CD20-directed } \\
\text { cytolytic antibody }\end{array}$ & RECITAL (NCT01862926) & $\begin{array}{l}\text { Patients with } \\
\text { CTD-ILD; } \\
n=116\end{array}$ & $\begin{array}{l}\text { Changes from baseline } \\
\text { in FVC at week } 24 \\
\text { (primary endpoint) } \\
\text { and week } 48 \\
\text { (secondary endpoint) }\end{array}$ & November 2019 \\
\hline
\end{tabular}

${ }^{a}$ According to ClinicalTrials.gov (accessed 12 November 2018)

CRISS Combined Response Index in Diffuse Systemic Sclerosis, CTD-ILD connective tissue disease-associated interstitial lung disease; 
therapy, in patients with progressive ILD of various etiologies [62] was terminated early due to slow recruitment and is yet to report results.

Interleukin-6 (IL-6), a pro-inflammatory cytokine, may play several roles in the pathogenesis of SSc, including promoting the differentiation of $\mathrm{B}$-cells to immunoglobulin-secreting plasma cells, the differentiation of T-cells towards a Th17 phenotype, and the transformation of fibroblasts to myofibroblasts [63]. The efficacy and safety of an anti-IL-6 monoclonal antibody, tocilizumab, in patients with SSc have been investigated in two trials. In the Phase II faSScinate trial in patients with progressive SSc $(N=87)$, there was no significant difference between tocilizumab and placebo in the primary endpoint of change in mRSS at week 24 but exploratory analyses suggested that tocilizumab may be associated with clinically relevant improvements in lung function [64]. In the Phase III focuSSced trial in 210 patients with SSc, the primary endpoint of change in mRSS at week 48 was not met. In exploratory analyses, the mean change from baseline in FVC at week 48 was $-0.4 \%$ predicted in the tocilizumab group versus $-4.6 \%$ predicted in the placebo group and the proportion of patients with a decline in FVC of $>10 \%$ predicted at week 48 was $5.4 \%$ with tocilizumab and $16.5 \%$ with placebo [65].

Several other compounds, with a variety of mechanisms of action, are being investigated as potential therapies for SSc-ILD in Phase II/III clinical trials [Table 1].

\section{Conclusions}

ILD is a common manifestation of SSc that is associated with early mortality. After diagnosis, all patients with SSc can benefit from an HRCT scan of the chest, PFTs, and assessment of respiratory symptoms. As the development or progression of ILD can occur at any time, patients should be monitored regularly, particularly in the first few years after diagnosis. Treatment should be considered when the disease is clinically significant, particularly when there is evidence of progression based on a decline in lung function, progression of fibrosis on HRCT, or worsening of respiratory symptoms. Currently treatment of SSc-ILD focuses on immunosuppressant therapies, particularly CYC and MMF. A number of new therapies with differing mechanisms of action are under active investigation.

\section{Abbreviations}

ACR: American College of Rheumatology; bid: twice daily;

CYC: Cyclophosphamide; dcSSc: diffuse cutaneous systemic sclerosis; DLco: Diffusion capacity of the lung for carbon monoxide; ERS: European Respiratory Society; EULAR: European League Against Rheumatism Collaborative Initiative; EUSTAR: EULAR Scleroderma Trials and Research Group; FVC: Forced vital capacity; HRCT: High resolution computed tomography; HRQL: Health-related quality of life; HSCT: Haematopoietic stem cell transplantation; ILD: Interstitial lung disease; IPF: Idiopathic pulmonary fibrosis; ICSSc: limited cutaneous systemic sclerosis; MMF: Mycophenolate mofetil; mRSS: modified Rodnan skin score; NSIP: Non-specific interstitial pneumonia; PFTs: Pulmonary function tests; PH, SGRQ: St George's Respiratory Questionnaire; SLS: Scleroderma Lung Study; SSc: Systemic sclerosis; SSc-ILD: Interstitial lung disease associated with systemic sclerosis

\section{Acknowledgements}

Medical writing assistance, supported financially by Boehringer Ingelheim, was provided by Melanie Stephens and Wendy Morris of FleishmanHillard Fishburn, London, UK during the preparation of this article. The authors were fully responsible for all content and editorial decisions, were involved at all stages of manuscript development, and have approved the final version.

\section{Funding}

The page processing charges for this article have been paid by Boehringer Ingelheim. The authors have received no payment to write this article.

\section{Availability of data and materials}

Not applicable.

\section{Authors' contributions}

Both authors were involved in the writing and review of this article and meet criteria for authorship as recommended by the International Committee of Medical Journal Editors (ICMJE). Both authors read and approved the final manuscript.

Ethics approval and consent to participate Not applicable.

\section{Consent for publication}

Not applicable.

\section{Competing interests}

Vincent Cottin has received consultancy fees from Actelion, Bayer, Boehringer Ingelheim, Galapagos, Gilead, Merck Sharp \& Dohme, Novartis, Roche, Sanofi; fees for being a member of Data and Safety Monitoring Boards from Celgene, Galapagos, Promedior; and grants paid to his institution from Boehringer Ingelheim and Roche. Kevin Brown has received personal fees from AstraZeneca, Bayer, Biogen Idec, Boehringer Ingelheim, Galapagos, Galecto, Gilead, Medlmmune, Novartis, Aeolus, ProMetic, Patara, Third Pole and aTyr, as well as grants from NHLBI.

\section{Publisher's Note}

Springer Nature remains neutral with regard to jurisdictional claims in published maps and institutional affiliations.

\section{Author details}

${ }^{1}$ National Reference Center for Rare Pulmonary Diseases, Louis Pradel Hospital, Claude Bernard University Lyon 1, 28 Avenue du Doyen Lepine, 69677 Lyon Cedex, Lyon, France. ${ }^{2}$ National Jewish Health, 1400 Jackson Street, Denver, CO 80206, USA.

Received: 13 June 2018 Accepted: 7 January 2019

Published online: 18 January 2019

\section{References}

1. Muangchan J. Canadian scleroderma research group, Baron M, Pope J. The $15 \%$ rule in scleroderma: the frequency of severe organ complications in systemic sclerosis. A systematic review. J Rheumatol. 2013:40:1545-56.

2. Varga J, Abraham D. Systemic sclerosis: a prototypic multisystem fibrotic disorder. J Clin Invest. 2007;117:557-67.

3. Wollheim FA. Classification of systemic sclerosis. Visions and reality Rheumatology. 2005;44:1212-6.

4. Steele R, Hudson M, Lo E, Baron M. Canadian scleroderma research group. Clinical decision rule to predict the presence of interstitial lung disease in systemic sclerosis. Arthritis Care Res (Hoboken). 2012;64:519-24.

5. Vonk MC, Broers B, Heijdra YF, Ton E, Snijder R, van Dijk AP, et al. Systemic sclerosis and its pulmonary complications in the Netherlands: an epidemiological study. Ann Rheum Dis. 2009;68:961-5.

6. van den Hoogen F, Khanna D, Fransen J, Fransen J, Johnson SR, Baron M, et al. 2013 classification criteria for systemic sclerosis: an American College of 
Rheumatology/European league against rheumatism collaborative initiative. Arthritis Rheum. 2013;65:2737-47.

7. Fischer A, Brown KK. Interstitial lung disease in undifferentiated forms of connective tissue disease. Arthritis Care Res (Hoboken). 2015;67:4-11.

8. Nihtyanova SI, Schreiber BE, Ong VH, Rosenburg D, Moinzadeh P, Coghlan $\mathrm{JG}$, et al. Prediction of pulmonary complications and long-term survival in systemic sclerosis. Arthritis Rheumatol. 2014;66:1625-35.

9. Steen V, Domsic RT, Lucas M, Fertig N, Medsger TA. A clinical and serologic comparison of African-American and Caucasian patients with systemic sclerosis. Arthritis Rheum. 2012;64:2986-94.

10. Jaeger VK, Wirz EG, Allanore Y, Rossbach P, Riemekasten G, Hachulla E, et al. Incidences and risk factors of organ manifestations in the early course of systemic sclerosis: a longitudinal EUSTAR study. PLoS One. 2016;11: e0163894.

11. Theodore AC, Tseng CH, Li N, Elashoff RM, Tashkin DP. Correlation of cough with disease activity and treatment with cyclophosphamide in scleroderma interstitial lung disease: findings from the scleroderma lung study. Chest. 2012;142:614-21.

12. Desai SR, Veeraraghavan S, Hansell DM, Nikolakopolou A, Goh NS, Nicholson $A G$, et al. $C T$ features of lung disease in patients with systemic sclerosis: comparison with idiopathic pulmonary fibrosis and nonspecific interstitial pneumonia. Radiology. 2004;232:560-7.

13. Enomoto $Y$, Nakamura $Y$, Colby TV, Johkoh T, Sumikawa H, Nishimoto $K$, et al. Radiologic pleuroparenchymal fibroelastosis-like lesion in connective tissue disease-related interstitial lung disease. PLoS One. 2017;12(6): e0180283.

14. Bouros D, Wells AU, Nicholson AG, Colby TV, Polychronopoulos V, Pantelidis $P$, et al. Histopathologic subsets of fibrosing alveolitis in patients with systemic sclerosis and their relationship to outcome. Am J Respir Crit Care Med. 2002;165:1581-6.

15. Denton CP, Khanna D. Systemic sclerosis. Lancet. 2017. https://doi.org/10. 1016/S0140-6736(17)30933-9.

16. Tashkin DP, Elashoff R, Clements PJ, Goldin J, Roth MD, Furst DE, et al. Cyclophosphamide versus placebo in scleroderma lung disease. N Engl J Med. 2006;354:2655-66.

17. Suliman YA, Dobrota R, Huscher D, Nguyen-Kim TD, Maurer B, Jordan S, et al. Brief report: pulmonary function tests: high rate of false-negative results in the early detection and screening of scleroderma-related interstitial lung disease. Arthritis Rheumatol. 2015;67:3256-61.

18. Antoniou KM, Margaritopoulos GA, Goh NS, Karagiannis K, Desai SR, Nicholson AG, et al. Combined pulmonary fibrosis and emphysema in scleroderma-related lung disease has a major confounding effect on lung physiology and screening for pulmonary hypertension. Arthritis Rheumatol. 2016;68:1004-12

19. Wigley FM, Lima JA, Mayes M, McLain D, Chapin IL, Ward-Able C. The prevalence of undiagnosed pulmonary arterial hypertension in subjects with connective tissue disease at the secondary health care level of community-based rheumatologists (the UNCOVER study). Arthritis Rheum. 2005;52:2125-32.

20. Galiè N, Humbert M, Vachiery JL, Gibbs S, Lang I, Torbicki A, et al. 2015 ESC/ ERS Guidelines for the diagnosis and treatment of pulmonary hypertension: the joint task force for the diagnosis and treatment of pulmonary hypertension of the European Society of Cardiology (ESC) and the European Respiratory Society (ERS): Endorsed by: Association for European Paediatric and Congenital Cardiology (AEPC), International Society for Heart and Lung Transplantation (ISHLT). Eur Heart J. 2016:37:67-119.

21. Steen VD, Medsger TA. Changes in causes of death in systemic sclerosis, 1972-2002. Ann Rheum Dis. 2007:66:940-4

22. Tyndall AJ, Bannert B, Vonk M, Airò P, Cozzi F, Carreira PE, et al. Causes and risk factors for death in systemic sclerosis: a study from the EULAR scleroderma trials and research (EUSTAR) database. Ann Rheum Dis. 2010;69:1809-15.

23. Elhai M, Meune C, Boubaya M, Avouac J, Hachulla E, Balbir-Gurman A, et al. Mapping and predicting mortality from systemic sclerosis. Ann Rheum Dis. 2017;76:1897-905.

24. Le Gouellec N, Duhamel A, Perez T, Hachulla AL, Sobanski V, Faivre J, et al. Predictors of lung function test severity and outcome in systemic sclerosisassociated interstitial lung disease. PLoS One. 2017;12:e0181692.

25. Steen VD, Medsger TA Jr. Severe organ involvement in systemic sclerosis with diffuse scleroderma. Arthritis Rheum. 2000;43:2437-44.

26. Man A, Davidyock T, Ferguson LT, Leong M, Zhang Y, Simms RW. Changes in forced vital capacity over time in systemic sclerosis: application of groupbased trajectory modelling. Rheumatology (Oxford). 2015;54:1464-71.
27. Goh NS, Hoyles RK, Denton CP, Hansell DM, Renzoni EA, Maher TM, et al. Short-term pulmonary function trends are predictive of mortality in interstitial lung disease associated with systemic sclerosis. Arthritis Rheumatol. 2017:69:1670-8.

28. Khanna D, Tseng CH, Farmani N, Steen V, Furst DE, Clements PJ, et al. Clinical course of lung physiology in patients with scleroderma and interstitial lung disease: analysis of the Scleroderma Lung Study placebo group. Arthritis Rheum. 2011;63:3078-85.

29. Kim HJ, Tashkin DP, Gjertson DW, Proudman SM, Dalbeth N, Matteson EL, et al. Transitions to different patterns of interstitial lung disease in scleroderma with and without treatment. Ann Rheum Dis. 2016;75:1367-71.

30. Goh NS, Desai SR, Veeraraghavan S, Hansell DM, Copley SJ, Maher TM, et al. Interstitial lung disease in systemic sclerosis: a simple staging system. Am J Respir Crit Care Med. 2008;177:1248-54.

31. Winstone TA, Assayag D, Wilcox PG, Dunne JV, Hague CJ, Leipsic J, et al. Predictors of mortality and progression in scleroderma-associated interstitial lung disease: a systematic review. Chest. 2014;146:422-36.

32. Adler S, Huscher D, Siegert E, Allanore Y, Czirják L, DelGaldo F, et al. Systemic sclerosis associated interstitial lung disease - individualized immunosuppressive therapy and course of lung function: results of the EUSTAR group. Arthritis Res Ther. 2018;20:17.

33. Kowal-Bielecka O, Fransen J, Avouac J, Becker M, Kulak A, Allanore T, et al. Update of EULAR recommendations for the treatment of systemic sclerosis. Ann Rheum Dis. 2017;76:1327-39.

34. Kowal-Bielecka O, Landewé R, Avouac J, Chwiesko S, Miniati I, Czirjak L, et al. EULAR recommendations for the treatment of systemic sclerosis: a report from the EULAR scleroderma trials and research group (EUSTAR). Ann Rheum Dis. 2009;68:620-8.

35. Tashkin DP, Roth MD, Clements PJ, Furst DE, Khanna D, Kleerup EC, et al. Mycophenolate mofetil versus oral cyclophosphamide in sclerodermarelated interstitial lung disease (SLS II): a randomised controlled, doubleblind, parallel group trial. Lancet Respir Med. 2016:4:708-19.

36. Silver KC, Silver RM. Management of systemic-sclerosis-associated interstitial lung disease. Rheum Dis Clin N Am. 2015;41:439-57.

37. Volkmann ER, Tashkin DP. Treatment of systemic sclerosis-related interstitial lung disease: a review of existing and emerging therapies. Ann Am Thorac Soc. 2016;13:2045-56.

38. Hoyles RK, Ellis RW, Wellsbury J, Lees B, Newlands P, Goh NS, et al. A multicenter, prospective, randomized, double-blind, placebo-controlled trial of corticosteroids and intravenous cyclophosphamide followed by oral azathioprine for the treatment of pulmonary fibrosis in scleroderma. Arthritis Rheum. 2006:54:3962-70.

39. Tashkin DP, Elashoff R, Clements PJ, Roth MD, Furst DE, Silver RM, et al. Effects of 1-year treatment with cyclophosphamide on outcomes at 2 years in scleroderma lung disease. Am J Respir Crit Care Med. 2007;176:1026-34

40. Roth MD, Tseng CH, Clements PJ, Furst DE, Tashkin DP, Goldin JG, et al. Predicting treatment outcomes and responder subsets in sclerodermarelated interstitial lung disease. Arthritis Rheum. 2011;63:2797-808.

41. Walker KM, Pope J. Participating members of the scleroderma clinical trials consortium (SCTC); Canadian scleroderma research group (CSRG). Treatment of systemic sclerosis complications: what to use when first-line treatment fails--a consensus of systemic sclerosis experts. Semin Arthritis Rheum. 2012:42:42-55.

42. Omair MA, Alahmadi A, Johnson SR. Safety and effectiveness of mycophenolate in systemic sclerosis. A systematic review. PLoS One. 2015; 10:e0124205.

43. van Laar JM, Farge D, Sont JK, Naraghi K, Marjanovic Z, Larghero J, et al. Autologous hematopoietic stem cell transplantation vs intravenous pulse cyclophosphamide in diffuse cutaneous systemic sclerosis: a randomized clinical trial. JAMA. 2014;311:2490-8.

44. Burt RK, Shah SJ, Dill K, Grant T, Gheorghiade M, Schroeder J, et al. Autologous non-myeloablative haemopoietic stem-cell transplantation compared with pulse cyclophosphamide once per month for systemic sclerosis (ASSIST): an open-label, randomised phase 2 trial. Lancet. 2011;378: 498-506.

45. Sullivan KM, Goldmuntz EA, Keyes-Elstein L, McSweeney PA, Pinckney A, Welch $B$, et al. Myeloablative autologous stem-cell transplantation for severe scleroderma. N Engl J Med. 2018;378:35-47.

46. Weill D, Benden C, Corris PA, Dark JH, Davis RD, Keshavjee S, et al. A consensus document for the selection of lung transplant candidates: 2014an update from the Pulmonary Transplantation Council of the International 
Society for Heart and Lung Transplantation. J Heart Lung Transplant. 2015; 34:1-15.

47. Pradère P, Tudorache I, Magnusson J, Savale L, Brugiere O, Douvry B, et al. Lung transplantation for scleroderma lung disease: an international, multicenter, observational cohort study. J Heart Lung Transplant. 2018;37:903-11.

48. Crespo MM, Bermudez CA, Dew MA, Johnson BA, George MP, Bhama J, et al. Lung transplant in patients with scleroderma compared with pulmonary fibrosis. Short- and long-term outcomes. Ann Am Thorac Soc. 2016;13:84-92.

49. Garvey C. Interstitial lung disease and pulmonary rehabilitation. J Cardiopulm Rehabil Prev. 2010;30:141-6.

50. Willems LM, Vriezekolk JE, Schouffoer AA, Poole JL, Stamm TA, Boström C, et al. Effectiveness of nonpharmacologic interventions in systemic sclerosis: a systematic review. Arthritis Care Res (Hoboken). 2015;67:1426-39.

51. Lanken PN, Terry PB, Delisser HM, Fahy BF, Hansen-Flaschen J, Heffner JE, et al. An official American Thoracic Society clinical policy statement: palliative care for patients with respiratory diseases and critical illnesses. Am J Respir Crit Care Med. 2008;177:912-27.

52. Huang J, Beyer C, Palumbo-Zerr K, Zhang Y, Ramming A, Distler A, et al. Nintedanib inhibits fibroblast activation and ameliorates fibrosis in preclinical models of systemic sclerosis. Ann Rheum Dis. 2016;75:883-90

53. Huang J, Maier C, Zhang Y, Soare A, Dees C, Beyer C, et al. Nintedanib inhibits macrophage activation and ameliorates vascular and fibrotic manifestations in the Fra2 mouse model of systemic sclerosis. Ann Rheum Dis. 2017;76:1941-8.

54. Wollin L, Maillet I, Quesniaux V, Holweg A, Ryffel B. Antifibrotic and antiinflammatory activity of the tyrosine kinase inhibitor nintedanib in experimental models of lung fibrosis. J Pharmacol Exp Ther. 2014;349: 209-20.

55. Distler O, Brown KK, Distler JHW, Assassi S, Maher TM, Cottin V, et al. Design of a randomised, placebo-controlled clinical trial of nintedanib in patients with systemic sclerosis-associated interstitial lung disease (SENSCIS). Clin Exp Rheumatol. 2017;35:75-81.

56. Saketkoo LA, Mittoo S, Frankel S, LeSage D, Sarver C, Phillips K, et al. Reconciling healthcare professional and patient perspectives in the development of disease activity and response criteria in connective tissue disease-related interstitial lung diseases. J Rheumatol. 2014;41:792-8.

57. Conte $\mathrm{E}$, Gili $\mathrm{E}$, Fagone $\mathrm{E}$, Fruciano M, lemmolo M, Vancheri C. Effect of pirfenidone on proliferation, TGF- $\beta$-induced myofibroblast differentiation and fibrogenic activity of primary human lung fibroblasts. Eur J Pharm Sci. 2014;58:13-9.

58. Inomata M, Kamio K, Azuma A, Matsuda K, Kokuho N, Miura Y, et al. Pirfenidone inhibits fibrocyte accumulation in the lungs in bleomycininduced murine pulmonary fibrosis. Respir Res. 2014;15:16.

59. Lehtonen ST, Veijola A, Karvonen H, Lappi-Blanco E, Sormunen R, Korpela S, et al. Pirfenidone and nintedanib modulate properties of fibroblasts and myofibroblasts in idiopathic pulmonary fibrosis. Respir Res. 2016;17:14.

60. Didiasova M, Wilhem J, Kwapiszewska G, Wujak L, Zakrzewicz D, Schaefer L, et al. Pirfenidone exerts antifibrotic effects through inhibition of GLI transcription factors. FASEB J. 2017;31:1916-28.

61. Khanna D, Albera C, Fischer A, Khalidi N, Raghu G, Chung L, et al. An openlabel, phase II study of the safety and tolerability of pirfenidone in patients with scleroderma-associated interstitial lung disease: the LOTUSS trial. J Rheumatol. 2016;43:1672-9.

62. Behr J, Neuser P, Prasse A, Kreuter M, Rabe K, Schade-Brittinger C, et al. Exploring efficacy and safety of oral pirfenidone for progressive, non-IPF lung fibrosis (RELIEF) - a randomized, double-blind, placebo-controlled, parallel group, multi-center, phase II trial. BMC Pulm Med. 2017:17:122.

63. O'Reilly S, Cant R, Ciechomska M, van Laar JM. Interleukin-6: a new therapeutic target in systemic sclerosis? Clin Trans Immunology. 2013;2:e4.

64. Khanna D, Denton CP, Jahreis A, van Laar JM, Frech TM, Anderson ME, et al. Safety and efficacy of subcutaneous tocilizumab in adults with systemic sclerosis (faSScinate): a phase 2, randomised, controlled trial. Lancet. 2016; 387:2630-40.

65. Khanna D, Lin CJF, Kuwana M, Allanore Y, Batalov A, Butrimieneet I, et al. Efficacy and safety of tocilizumab for the treatment of systemic sclerosis: Results from a phase 3 randomized controlled trial. Chicago: Oral presentation at the American College of Rheumatology (ACR)/Association of Rheumatology Professionals (ARHP) annual meeting; 2018.

\section{Ready to submit your research? Choose BMC and benefit from:}

- fast, convenient online submission

- thorough peer review by experienced researchers in your field

- rapid publication on acceptance

- support for research data, including large and complex data types

- gold Open Access which fosters wider collaboration and increased citations

- maximum visibility for your research: over $100 \mathrm{M}$ website views per year

At $\mathrm{BMC}$, research is always in progress.

Learn more biomedcentral.com/submissions 